Saudi Journal of Humanities and Social Sciences

Abbreviated Key Title: Saudi J Humanities Soc Sci

ISSN 2415-6256 (Print) | ISSN 2415-6248 (Online)

Scholars Middle East Publishers, Dubai, United Arab Emirates

Journal homepage: https://saudijournals.com

Original Research Article

\title{
Scientific Based Learning Activities with Assessment Presentation and Class Management Techniques
}

\author{
Sujarwo $^{1^{*}}$, Dara Fitrah Dwi ${ }^{2}$, Rosmilan Pulungan ${ }^{3}$
}

Universitas Muslim Nusantara (UMN) Al-Washliyah

DOI: $\underline{10.36348 / \mathrm{sjhss} .2020 . \mathrm{v} 05 \mathrm{i} 12.002}$

| Received: 16.11 .2020 | Accepted: 28.11 .2020 | Published: 05.12.2020

*Corresponding author: Sujarwo

\section{Abstract}

Learning for students was to master the material in the purpose of facing the learning evaluation, and it was requiring a maximum ability. In fact, there were students who were not able to master the material. This situation informed that there was a low learning activity. This problems could be solved by having a scientific learning activities based using assignment techniques and classroom management. Learning activities were shown through the involvement of students in physical and mental activities by completing assignments both inside and outside the classroom. And it was done using scientific principles in order to create a conducive atmosphere and optimal learning maintenance. The exploratory method was carried out during the learning process at elementary school teacher education study program of UMN AlWashliyah. Before the learning activities begun, it was done earlier by controlling and coordinating the class preparation for presenting the results of the assignments. Learning activities were begun through the steps and process of observation, asking questions, collecting information by experimenting, processing information and communicating. The technique of presenting the results of the assignment was debate, which meant that all students should prepare themselves mentally about the material being discussed. When the presenter reviewed the material, the examiner can be directly asking or objecting to the review of the material presented by the presenter. Apart from that, the audience was allowed to ask some related questions.

Keywords: Learning activity, Scientific, Assessment technique, Class management.

Copyright $\odot 2020$ The Author(s): This is an open-access article distributed under the terms of the Creative Commons Attribution 4.0 International License (CC BY-NC 4.0) which permits unrestricted use, distribution, and reproduction in any medium for non-commercial use provided the original author and source are credited.

\section{INTRODUCTION}

Learning becomes a culture for students in master the material in facing learning evaluation in the form of exams. Therefore, learning requires the maximum ability of students through cooperative task completion in order to increase understanding. Thus, students have experience so that they can recall experiences that have occurred, especially the material that was delivered at the time of presenting the assignment.

However, there are still students who do not show maximum results, there is no visible increase in mastery of the material, instead what appears is presenting the results of the discussion by reading the writing that has been prepared on a piece of paper, even though what is read is already included on a power point slide. They also don't pay attention and maximize the material they have prepared in the form of power points. The stage fright seemed to tell them that they were completely unprepared and overpowered the material. Fingers trembled when holding the paper containing the material that was already in the power point.

This situation shows the low learning activity that occurs so that changes need to be made for improvement with various techniques and management. To overcome this, efforts to increase learning activities can be done on a scientific basis using assignment techniques and classroom management.

\section{BASIC THEORY}

1. The Learning Activities

Learning activities are a reflection of the presence or absence of learning. Without activity, learning is invisible. Therefore, activity is a principle in teaching and learning interactions [1]. Learning activities are the involvement of students in the form of attitudes, thoughts, attention, in physical and mental activities $[2,3]$ where learning activities are interrelated [4]. 
Referring to the conclusion of the research results of Zakiah, et al. [5] that the application of the assignment method can increase learning activities. Student activities that are already good are the readiness of students to take part in lessons, the attention of students in learning, the courage to ask the teacher, ask questions among students, do assignments well, enthusiastically participate in lessons The conclusion of the research results of Ulfaira, et al. [6] that student learning activities continue to increase from the preaction stage to the first cycle of action, to the second cycle of action.

The high intensity of learning activities carried out shows the learning acquisition in accordance with expectations. Conversely, the low intensity of learning activities that occurs shows results that are not as expected [7].

\section{The display of Assignment result}

Djamarah and Zain [8] state that the assignment method is a way of presenting material in Sutarna [9] where the teacher assigns certain tasks in order to carry out learning activities [10] in Setyowati [11]. Slameto [12] reveals that the assignment method is a way of delivering material by giving assignments to students to be done outside the schedule within a certain timeframe and the results must be accounted for [13]. Therefore, completion of assignments can be done in class or outside the classroom such as on the page school in the library, in the workshop, in the laboratory, at home or where the important thing is that the task is done and finished.
From some of the opinions above, it can be concluded that the assignment method is the delivery of material through assignments that can be done outside of class learning activities according to the specified timeframe and the results are presented by presenting the results of the assignments in front of classmates.

\section{Scientific Learning}

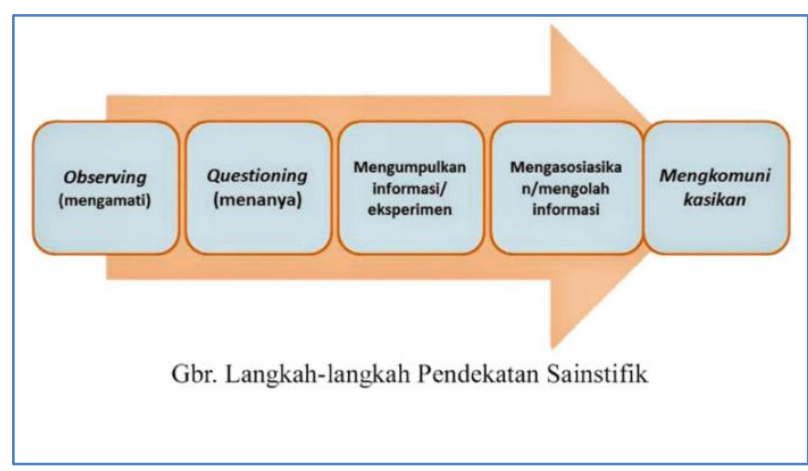

Scientific comes from Latin, namely scientia, in English, namely science which means knowledge or knowing. Learning can be interpreted as a collection of methods used by educators in learning [14]. By implementing science, learning is more active, not boring, students build their knowledge and skills through facts found in the field [15] through a process of seeking knowledge with scientific process activities Laelasari [16] used scientific principles in the learning process [17].

\begin{tabular}{|c|c|}
\hline Steps & Learning Activities \\
\hline Observing & $\begin{array}{l}\text { Students are directed to observe by reading learning resources, hearing information on study materials, } \\
\text { seeing (with or without tools). } \\
\text { The ability to be achieved through observing experience is thoroughness, seriousness and being able to } \\
\text { find relevant information with study material. }\end{array}$ \\
\hline Questioning & $\begin{array}{l}\text { Stimulating and / or without stimulation students ask questions related to the study material presented, } \\
\text { especially on study material that is not understood from what is observed, or questions to obtain } \\
\text { additional information about what they are observing. The questions asked can be factual. } \\
\text { The ability that is expected to be achieved is the growth and development of scientific thinking } \\
\text { creativity through curiosity shown by honesty. }\end{array}$ \\
\hline $\begin{array}{l}\text { Colle } \\
\text { Inforr }\end{array}$ & $\begin{array}{l}\text { Directing students to do learning activities that add to their experience by experimenting, reading } \\
\text { various sources of information, observing objects, remembering and observing abstractly phenomena } \\
\text { that have occurred, to interviewing someone as a source of information. } \\
\text { The ability that is expected to be achieved is that students show courage, honest, and able to } \\
\text { communicate. }\end{array}$ \\
\hline $\begin{array}{l}\text { Processing } \\
\text { information }\end{array}$ & $\begin{array}{l}\text { Directing students to show the results of information processing ranging from a variety of information } \\
\text { that deepens and expands information to mutually supportive, even different or contradictory } \\
\text { information. } \\
\text { The ability to be achieved is that students are able to synergize various information in the form of } \\
\text { conclusions comprehensively, so that, among others, students are able to show obedience to rules, work } \\
\text { hard, are able to implement a procedure. }\end{array}$ \\
\hline Communicating & $\begin{array}{l}\text { Directing students to present the results of their information processing in the form of presentations and } \\
\text { other relevant forms. } \\
\text { The ability to be developed is that students demonstrate their ability to develop honesty, } \\
\text { conscientiousness, tolerance, think systematically, express opinions in a concise and clear way, and } \\
\text { have the ability to speak properly and correctly. }\end{array}$ \\
\hline
\end{tabular}

Source: Musfiqon, Nudyansyah. 2015. Pendekatan Pembelajaran Sainstifik. Sidoarjo: Nizamia Learning Center 


\section{Classroom management}

Mulyasa [18] in Sujarwo [7] states that classroom management is a teacher's skill to create a conducive learning climate, and control it if there is a disruption in learning. Class management skills consist of a) the creation and maintenance of an optimal learning climate, b) skills related to controlling optimal learning conditions.

\section{METHOD}

The research had been done during the learning process by implementing the explorative method, at elementary school teacher education study program of University of Muslim Nusantara (UMN) Al Washliyah.. The research sample was the fourth semester students of elementary school teacher education study program (PGSD) of UMN Al-Washliyah The technique used to collect the data was doing observations when learning activities and learning evaluations took place.

\section{RESULT AND DISCUSSION}

\section{Classroom Management Technique}

Before learning activities are carried out, first step would be done was arranging student seats, which were ten chairs in the middle of the class. The ten seats are divided into two facing each other, namely five seats facing west and the other five seats facing east. While the other chairs are arranged to form a $\mathrm{U}$ letter behind the ten chairs which have been divided into 2 parts and adjacent to the classroom wall.

Seating arrangements are used to present the results of the assignment which consists of three groups, namely the presenter group, the examiner group and / or the moderator and the audience group. The presenter group is a team that is obliged to present the results of the assignment. Meanwhile, the examiner and / or moderator group is a creative team and examiners who are obliged to organize the course of the event and test the material reviews submitted by the presenter team. Audience groups are groups that have not presented the results of their assignment so they become participants and questioners.

To clarify the order of changes, classroom management techniques, especially in seating arrangements from ordinary to scientific-based arrangements, are shown in the image below:

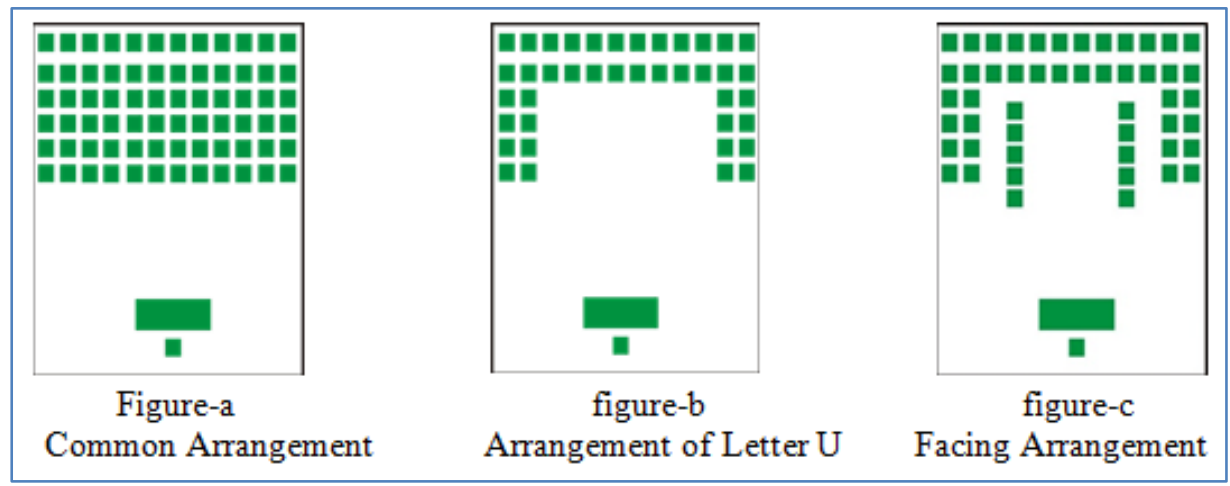

Figure a above is a classroom management technique in common that occurs in all classes in every education provider. The classroom management technique in figure a has an impact on a) obstruction of the eyes of students who are behind. The more backward, the view of the students behind the more obstructed by the students sitting in front of them, b) the creation of conversation between students, c) the amount of opportunity to control the gadget because it was blocked by the students in front of them, d) the low involvement of students in learning well mentally or physically.

To minimize the impact that occurs on the class a drawing class management technique, changes are made so that a drawing class management technique is formed b. However, the management technique in Figure $b$ has an impact on the difficulty of implementing the presentation of the results of the assignment. Therefore, to accommodate this, a classroom management technique was formed in Figure c. Thus, the classroom management technique in Figure c is used for the technique of presenting the results of the assignment. One of the things that underlie it is to create and maintain a conducive learning climate [18, 19].

\section{Scientific- based learning activity}

The learning activity begins with reading the Qur'anic letter Ash Shof verse 10 together then continues with learning prayers.

To make the learning process meaningful, students are given the opportunity to be involved in learning which refers to the scientific approach, namely learning activities that start with observation, asking questions, gathering information by experimenting, processing information and conveying information.

Scientific-based learning activities with assignment presentation techniques are carried out since the title of the material is informed to each group. Each group prepares the presentation material by collecting 
information on the assignment material according to mutual agreement between them.

Before carrying out the assignment presentation technique, students carry out learning according to the scientific stages, namely:

\section{a. Observing}

To gain knowledge, students in groups made observations in the environment around UMN AlWashliyah. Observations were made based on the given material, namely energy and its changes. Thus, the learning process that occurs, they carry out activities such as identifying, tracing, investigating, searching and finding related energy, energy use, and energy changes.

\section{b. Questioning}

The observations that have been made stimulate students to their curiosity, which raises questions. Questions that arise by each student they ask or they ask friends from one group, other group friends or to people around who are considered to be able to provide information.

\section{c. Collecting information/ Experimenting.}

After several stages were carried out, they then tried it directly. For example, when they investigate the energy change from one energy to another, namely when they find the energy changes made by the people they see when making observations, such the phenomenon of someone moving their hands when playing the guitar, from the movements of their hands producing the sound of the guitar strings. That way, other groups can do different things with the same principle that they move their hands so that it makes a sound like they are clapping their hands and it produced a sound from their clapping.

\section{a. Processing the Information}

Based on the information obtained, students show the results of the information they have obtained such as when students clap their hands to produce a sound. In fact, they get this information when they see someone playing the guitar at the time of observation.

\section{d. Communicating}

The results of observations until processing information will be communicated or disseminated through the presentation of the results of the assignments carried out in accordance with the techniques of presenting the results of assignments and class management.

\section{The technique of Presenting assignment}

Science-based learning activities are controlled by educators through material which is realized by learning activities. How to make it happen by giving an assignment. The presentation technique refers to the classroom management technique in Figure c above.
To begin presenting the results of the assignment, five students of the presenter team are welcome to sit in chairs facing west and five students of the examining team and / or moderators to sit in chairs facing east. Other students sit in audience seats forming the letter $\mathrm{U}$.

Furthermore, the examiners and / or moderators open the presentation of the results of the assignment which begins with greetings, prayers and provides a glimpse of the material to be delivered by the presenter, then invites the presenter team to present a review of the material.

The technique of presenting the results of the assignment is debate, so all students must prepare themselves mentally about the material being discussed. Because when the time of the presenting team presents a review of the material, the examiner team and / or moderator can directly ask or refute the review of the material presented by the presenter. In addition, the audience can also ask related questions after being welcomed by the examiners and / or moderators.

A review of the material that has been prepared shows that their learning activities are not only inside the classroom, but also occur outside the classroom, either individually or cooperatively.

Activities for learning activities that occur, it turns out, they are able to show that they master the material they have prepared, are courageous and able to answer questions under time pressure. Not only that, they also received rebuttals from the testing team and the audience for the answers they gave and could be resolved. The atmosphere of debate ensued between the presenter team, the examiner team and the audience. Conditions like this indicate that learning activities occur especially before the presentation of the results of the assignment which is supported by their experiences, both directly related to lectures and when they are closely related as teachers.

Thus, the technique of presenting the results of assignments that are debatable to student learning activities showed that the process that occurred is a process of understanding and mastering the material which becomes an experience for each student.

Almost all students who are members of each group show their characters such as being honest, brave and helping others. The presenter team showed courage in delivering material, arguing and answering questions and even strongly motivated to argue with the examiners. The examiners showed their courage in criticizing the material reviews by asking questions until there was a debate which showed that each of them tried to defend their arguments. In addition, they show an honest character related to the facts they find in 
the field when interacting with the wider community, especially in the educational environment.

\section{CONCLUSION}

Learning is intended for mastery of the material as preparation for learning evaluation because it demands maximum ability. Learning activities can be carried out on a scientific basis using assignment techniques and classroom management. Learning activities are shown through the involvement of students in physical and mental activities by completing tasks inside or outside the classroom using scientific principles in order to create an atmosphere and maintain optimal and conducive learning. Before learning activities, first arrange the class for presenting the results of the assignments. Learning activities begin with observation, asking questions, collecting information through experimenting, processing information and communicating. The technique of presenting the results of the assignment is debate, in purposing to support all students prepare themselves mentally about the material being discussed. When the presenter reviews the material, the examiner can directly ask or object to the review of the material presented by the presenter. Apart from that, the audience can also ask related questions.

Each group showed its character such as being honest, brave and helping others. The presenter team showed courage in delivering material, arguing, answering questions and even strongly motivated to argue with examiners. The examiners showed their courage to criticize the material reviews until a debate occurred to defend their arguments.

\section{REFERENCES}

1. Widayanti, L. (2013). Peningkatan aktivitas belajar dan hasil belajar siswa dengan metode problem based learning pada siswa kelas VIIA MTS Negeri Donomulyo Kulon Progo tahun pelajaran 2012/2013. Jurnal Fisika Indonesia, 17(49).

2. Arikunto, S. (2005). Manajemen penelitian edisi revisi. Jakarta: Rineka Cipta.

3. Ariasmini, N. (2019). Penerapan Metode Resitasi dalam Upaya Peningkatan Aktivitas dan Hasil Belajar Siswa pada Mata Pelajaran Akuntansi Kelas Xi Akuntansi 1 di Smk Negeri 1 Tejakula Tahun Pelajaran 2016/2017. Jurnal Pendidikan Ekonomi Undiksha, 10(2), 397-407.

4. Agustin, M., Yensy, N. A., \& Rusdi, R. (2017). Upaya Meningkatkan Aktivitas Belajar Siswa Dengan Menerapkan Model Pembelajaran Problem Posing Tipe Pre Solution Posing Di Smp Negeri 15 Kota Bengkulu. Jurnal Penelitian Pembelajaran Matematika Sekolah (JP2MS), 1(1), 66-72.

5. Zakiah, Z., Jamaluddi, J., \& Imran, I. Meningkatkan Aktivitas Belajar Siswa Kelas IV pada Pembelajaran PKn melalui Metode Pemberian Tugas di SD. Jurnal Kreatif Online, 1(2).

6. Ulfaira, U., Jamaludin, J., \& Septiwiharti, S. Meningkatkan Aktivitas Belajar Pada Siswa Kelas III di SDInpresMarantale Dalam Pembelajaran Pkn Melalui Penerapan Metode Pembelajaran Role Playing. Jurnal Kreatif Online, 3(3).

7. Sujarwo, S. (2016). Potensi kecenderungan cara belajar visual terhadap prestasi belajar mahasiswa. Jurnal penelitian pendidikan mipa, 1(1), 34-37.

8. Djamarah, B., \& Zain, A. (1995). Metode-Metode Pembelajaran.

9. Sutarna, N. (2016). Penerapan Metode Penugasan Untuk Meningkatkan Kemampuan Memahami Peta Pada Siswa Sekolah Dasar. Jurnal Geografi Gea, 16(1), 34-43.

10. Kurnia, U., \& Sudirman, K. H. (2005). Teknologi rehabilitasi dan reklamasi lahan terdegradasi. Teknologi Pengelolaan Lahan Kering: Menuju Pertanian Produktif dan Ramah Lingkungan. Pusat Penelitian dan Pengembangan Tanah dan Agroklimat, Bogor. Hal, 141-168.

11. Setyowati, L. (2015). Pengaruh Metode Pembelajaran Penugasan Dan Peran Orang Tua Terhadap Hasil Belajar Bahasa Inggris. DEIKSIS, 7(03), 227-236.

12. Slameto, D. (1991). Belajar dan Faktor-Fakor Yang Mempengaruhi Belajar. Jakarta: Rineka Cipta.

13. Suparti, S. (2014). Penggunaan Metode Penugasan atau Resitasi Untuk Meningkatkan Hasil Belajar Siswa Kelas III dalam Memahami Konsep Mengenal Pecahan Sederhana. PEDAGOGIA: Jurnal Pendidikan, 3(1), 54-66.

14. Musfiqon, N. (2015). Pendekatan Pembelajaran Sainstifik. Sidoarjo: Nizamia Learning Center

15. Ine, M. E. (2015). Penerapan pendekatan scientific untuk meningkatkan prestasi belajar siswa pada mata pelajaran ekonomi pokok bahasan pasar. In Prosiding Seminar Nasional (Vol. 9, pp. 269285).

16. Laelasari, N. (2016). Penerapan Pendekatan Sainstifik Untuk Mengembangkan Keterampilan Proses Sains dan Sikap Ilmiah Siswa Pada Konsep Kelarutan dan Hasil Kali Kelarutan. Available online: http://journal.uinsgd.ac.id/index.php/tadriskimiya/article/view/1159. Accessed at October, $31^{\text {st }} 2020$.

17. Daryanto. (2014). Pendekatan Pembelajaran Sainstifik Kurikulum 2013. Yogyakarta: Gava Media.

18. Mulyasa, E. (2008). Implementasi kurikulum tingkat satuan pendidikan: kemandirian guru dan kepala sekolah. Bumi Aksara.

19. Sujarwo, D.K.K. (2020). Pemerolehan Pengetahuan Melalui Proses Kognitif Pada Pembelajaran IPA. Webinar Hasil Penelitian-Universitas Muslim Nusantara (UMN) Al-Washliyah. 